\title{
LEGAL AND REGULATORY CONSIDERATIONS IN PLANT DECOMMISSIONING AND RATIONALIZATION PLANS
}

\author{
RICHARD A. NEUFELD and \\ GEOFFREY S. PASKUSKI*
}

\begin{abstract}
The liability of owners and operators of sites contaminated by industrial activity is imposed at common law and by statute. Under the statutory regime prior to the new Alberta Environmental Protection and Enhancement Act ("AEPEA"), the scope of liability was generally limited to ongoing operations and arguably extended to the active remediation of the site. Further, past owners of industrial sites escaped liability for their pollution-causing activities. Under the AEPEA, more stringent provisions exist that govern the decommissioning process, including significantly increased penalties for non-compliance and the indirect imposition of liability upon past owners and non-operators for pollution-causing events that occurred in the past or during the decommissioning process. The authors recommend a regulatory strategy in regard to a program of site decommissioning associated with gas processing capacity. They point out that potential conflicts arise between the new Environmental Appeal Board ("EAB") and the Energy Resources Conservation Board ("ERCB") as to their respective roles in the rationalization plan approval process. In order to avoid the potential for duplication of public hearings before the EAB and ERCB, the authors recommend that processing capacity rationalization proponents consider submitting an omnibus application to the ERCB detailing all the activities required to implement the rationalization plan.
\end{abstract}

\section{TABLE OF CONTENTS}

I. INTRODUCTION .................... 259

II. CURRENT OBLIGATIONS IN RESPECT OF THE PROPER DECOMMISSIONING OF INDUSTRIAL SITES $\ldots \ldots 260$

A. CONTAMINATED SITE LIABILITY

AT COMMON LAW . . . . . . . . . . . . . . . . 260

B. REGULATORY/STATUTORY DECOMMISSIONING

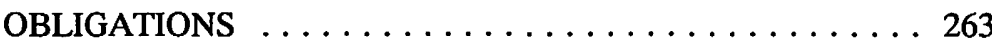

III. APPLICATION OF THE ALBERTA ENVIRONMENTAL PROTECTION AND ENHANCEMENT ACT TO A PROGRAM OF INDUSTRIAL SITE DECOMMISSIONING $\ldots \ldots \ldots \ldots \ldots 267$

A. REGULATION OF PLANTS UNDER THE AEPEA

- APPROVALS FOR DECOMMISSIONING AND

THE RECLAMATION PROCESS $\ldots \ldots \ldots \ldots \ldots \ldots 267$

B. INDIRECT LIABILITY AS A RESULT OF

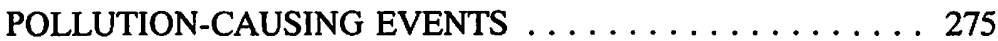

IV. REGULATORY ASPECTS OF OIL \& GAS FACILITY

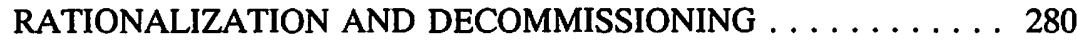

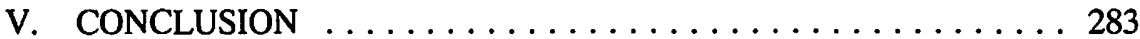

\section{INTRODUCTION}

The decommissioning of an industrial plant involves a broad and complex web of potential liability for pollution events. In addition to the statutory and regulatory

Barristers and Solicitors, Milner Fenerty, Calgary, Alberta. The authors gratefully acknowledge the assistance of Christopher F. Lee, Student-at-Law, Milner Fenerty. 
obligations imposed on operators in the decommissioning process, liability may also be imposed on joint facility owners or other non-operators for pollution-causing events either occurring or discovered in the decommissioning process.

While this may leave some operators and owners hesitant to embark upon decommissioning, the legal consequences of not properly decommissioning a production facility at common law and, most significantly, under the new Alberta Environmental Protection and Enhancement Act, ${ }^{1}$ do not render this a viable option. Accordingly, the best protection afforded to operators and owners is vigilance in ensuring that production facilities have been properly abandoned or decommissioned and that the sites have been reclaimed upon the cessation of production.

This paper is divided into three parts. The first part focuses on liability for contaminated sites at common law and under the statutory regime in place prior to the enactment of the AEPEA. Second, an analysis of the implications of the $A E P E A$ and associated regulations promulgated thereunder is offered. Third, the authors suggest a recommended regulatory strategy with respect to a program of site decommissioning associated with gas processing capacity.

\section{CURRENT OBLIGATIONS IN RESPECT OF THE PROPER DECOMMISSIONING OF INDUSTRIAL SITES}

\section{A. CONTAMINATED SITE LIABILITY AT COMMON LAW}

Prior to the advent of environmental legislation, liability for environmental damage was indirectly imposed by virtue of common law tort actions, most notably, an action in nuisance or strict liability by one landowner against another, or through the law of contract. Certainly, the operation of industrial plants and any proposed plan of decommissioning may result in common law liability in a number of ways, the most obvious being the release or potential release of contaminants from the plant into the environment. While industrial site owners and operators are not immune from tort or contract-based actions, the potential for common law liability, while not diminished, has been overshadowed by the standards and obligations imposed by legislation. Accordingly, only a brief overview of common law tort and contract principles, as they relate to the contaminated site liability, is offered.

\section{Nuisance}

Canadian judicial authorities have defined nuisance as the unreasonable interference with the use and enjoyment of another's land. In order to establish a nuisance, a plaintiff must prove either damage to the land itself, or a substantial discomfort in his or her use and enjoyment of such land. ${ }^{2}$ 
There are two types of nuisance: public nuisance and private nuisance. Public nuisance is based upon an unreasonable interference with a public interest, such as the public interest inherent in maintaining clean air and uncontaminated drinking water. The major limitation to promoting environmental protection through the use of public nuisance, however, is that, subject to a few minor exceptions, only the provincial Attorney General has standing to initiate an action. ${ }^{3}$ Hence, an action in public nuisance is undesirable, and indeed unavailable, for most plaintiffs.

Private nuisance, in contrast, is an unreasonable interference with the land in possession of another, either through a direct physical entry to the land, or by indirectly interfering with the use and enjoyment of the land. ${ }^{4}$

\section{Strict Liability}

Often, in respect of a nuisance action, a plaintiff will plead strict liability in the alternative. The principle of strict liability, also known as the rule in Rylands v. Fletcher, ${ }^{5}$ may be stated as follows:

The occupier of land who brings and keeps upon it anything likely to do damage if it escapes is bound at its peril to prevent its escape, and is liable for all the direct consequences of its escape, even if he has been guilty of no negligence.

The basis for a claim in strict liability is the isolated escape of dangerous substances from the defendant's land to the plaintiff's land as a result of the "non-natural" use of the land by the defendant.

\section{Negligence and Trespass}

Although often pled in the alternative to nuisance and strict liability, it is unusual for liability under negligence to be normally found, since an action for negligence poses two legal hurdles for the plaintiff which are not present in an action for nuisance. First, the plaintiff must show that the defendant owed a duty of care to the plaintiff. Second, the plaintiff must show that the damage was not so remote that the defendant could not reasonably have foreseen its occurrence. Accordingly, it is less desirable for a plaintiff to pursue an action based solely in negligence when, for the most part, an action for nuisance or strict liability is available.

An action in trespass is also normally unlikely to succeed. A plaintiff in a trespass action needs to show an unauthorized physical entry onto the plaintiff's land by the S.C.).

$4 \quad$ Solomon et al., Cases and Materials on the Law of Tort (Toronto: Carswell, 1986). It should be noted here that Canadian Courts have, to date, declined to adopt the reasoning used in certain American jurisdictions in which the concept of successor liability for environmental damage as an extension of the law of nuisance has been recognized. 
defendant, and further, that such entry interfered with the owner's exclusive possession of his or her land. Given that trespass requires a direct physical entry onto the plaintiff's land, a plaintiff may have difficulty establishing that the entry of a contaminant through the water, soil or air amounts to a trespass.

\section{Contractual Obligations}

In addition to tort-based actions, liability may also be imposed upon plant owners on the basis of contractual obligations. Canadian judicial authorities have adopted several unique methods to allow, in certain circumstances, the purchasers of contaminated sites to seek indemnity from the vendor. These include:

(a) The vendor of land on which is situate an inherently dangerous substance is guilty of fraud if he sells such land to a purchaser without warning the purchaser that, if the dangerous substance is not used or disposed of in a specified manner, or in a manner prescribed by statute, the purchaser and/or strangers to the contract may suffer a serious risk of injury. ${ }^{6}$

(b) In respect of latent (not apparent) defects, a vendor has a duty to disclose a latent defect which results in the premises being unfit for habitation. A vendor also has a duty to disclose dangerous latent defects.

(c) A vendor must disclose a latent defect if that latent defect results in the land being unsuitable for the plaintiff's purpose, and the plaintiff has communicated that purpose to the vendor. ${ }^{8}$

The owners of facilities to be shut down or abandoned without proper decommissioning and reclamation may therefore find it difficult to sell that site, or in the event of concealment of site defects, may face contractual liability to purchasers in the future.

Although at first glance, common law actions appear to be a significant source of liability for environmental damage to land, they have for the most part, been "hit or miss" propositions, producing divergent results. It is often the case that only after significant ascertainable damage has occurred to adjacent property that an action will be contemplated. In addition, once such actions are initiated they are often fraught with other legal difficulties. First, damages suffered by a party may not be directly attributable to the pollution-causing activity, thereby raising questions of causation. Second, environmental contamination may not be site-specific, thereby limiting the effectiveness of a separate action by one landowner. Third, since the court may balance the interests of both landowners in arriving at a decision, it is difficult to predict the outcome of any particular case. Finally, the sheer cost of maintaining an action may preclude any common law legal recourse. ${ }^{9}$

C.R.F. Holdings Limited v. Fundy Chemicals International Limited (1982), 19 C.C.L.T. 263.

McGrath v. McLean (1979), 95 D.L.R. (3d) 144.

Sevidal v. Chopra (1987), 41 C.C.L.T. 179.

See generally J.J. Marshall \& J.I. Parker, Common Law Liability for Environmental Damage (Insight Press, 1989); see also St. Pierre v. Ontario, [1987] 1 S.C.R. 906; Tock v. St. John's Metropolitan Area Board (1989), 104 N.R. 241 (S.C.C.). 


\title{
B. REGULATORY/STATUTORY DECOMMISSIONING OBLIGATIONS
}

Prior to the $A E P E A$, Alberta's general environmental legislation consisted of an array of statutes, most of which were "first generation" environmental laws enacted in the early 1970s. The primary statutes were the Clean Air Act ${ }^{10}$, the Clean Water Act ${ }^{11}$ and the Hazardous Chemical Act. ${ }^{12}$ In addition, the Safety Codes $A c t^{13}$ may impact upon a program of industrial site decommissioning. With the exception of the $S C A$, these statutes have been repealed by the $A E P E A$. However, a discussion of their provisions, as they relate to plant decommissionings, is warranted for two reasons. First, the prior legislation provides some context in which to discuss and grasp the changes implemented by the $A E P E A$. Second, under the transitional provisions of the $A E P E A$, licenses and permits issued under the former acts are grandfathered such that they are deemed to be approvals under the AEPEA until their expiry dates. Accordingly, one may need to refer to the predecessor acts in the event that issues arise with respect to compliance with the terms and conditions of such licenses and permits.

\section{Clean Air Act and Clean Water Act}

An example of the types of prohibitive provisions contained in general environmental statutes was found in s. 17 of the $C W A$, which contained a general prohibition over water pollution. The provision stated:

17(1) Subject to subsection (2), no person shall deposit or permit the deposit of a water contaminant
(a) in a watercourse,
(b) in surface water,
(c) in underground fresh water, or
(d) in any place under any conditions where that water contaminant or any other water contaminant that results from the deposit of the water contaminant may enter any watercourse, surface water or underground fresh water,

\begin{abstract}
if it degrades, alters or forms part of or is likely to degrade, alter or form part of the process of degradation or alteration of the chemical or biological quality of water, so that the water in the watercourse, surface water or underground fresh water is or is likely to be rendered harmful to human health or life, fish, wildlife, livestock or plants.
\end{abstract}

It was arguable that to avoid prosecution under this section of the $C W A$, remediation of a site was required and could, in fact, form the basis of a due diligence defence to the extent that the Crown alleged that continuous releases were taking place due to the contaminated condition of a site. ${ }^{14}$ 
In addition, where industrial processing facilities resulted in the deposit of contaminants on a site which is licensed under the $C W A$, a duty to remediate potentially arose. First, pursuant to s. 14, such spills could lead to a water quality control order being issued to the person owning or operating the plant, structure or thing that the Director of Pollution Control considered to be the source of the water contamination. Second, both the CAA (s. 14) and the CWA (s. 15) made provisions for the issuance of stop orders. Both pollution control orders and stop orders arguably extended to requiring active remediation measures. The pollution control order, however, was more significant than the stop order in the context of decommissioning where operations had already been discontinued.

No discrete requirement existed in the $C W A$, however, to obtain approval of site reclamation or decommissioning activities. Furthermore, in the absence of a pollution control order, determining whether a duty of site remediation existed in any particular circumstance was fraught with legal and factual difficulty. For example, the contamination of soil from past landfilling or underground storage activities was not in itself an offence under the $C W A$, unless it could be shown that ground water resources were contaminated to the extent of creating a risk to human health, fish, wildlife, livestock or plants.

\section{Hazardous Chemical Act}

When the substance involved in the pollution event was a hazardous chemical, a broader net of liability for administrative pollution control orders was possible under the $H C A$. Section 1(f) of the HCA defined "hazardous chemicals" as:

1(f) hazardous chemical means any substance, class of substance or mixture of substances that is entering or is capable of entering the environment in a quantity or concentration or under conditions that may constitute a danger to

(i) the environment,

(ii) plant or animal life, or

(iii) human health;

The HCA contained a somewhat broader definition of persons responsible for compliance than did the $C W A$ or $C A A$, statutes of earlier vintage. Section 1(j) of the $H C A$ defined "person responsible" as follows:

1(j) "person responsible", when used with reference to a hazardous chemical or a substance or thing containing a hazardous chemical, means

(i) its owner,

(ii) the person having the charge, management or control of it, and

(iii) the person having the charge, management or control of the handling, storage, use, disposal, transportation, or display of it;

The enforcement mechanism under the $H C A$ was contained in subsection $6(1)$, which allowed the Director of Pollution Control to issue orders to persons responsible for a 
hazardous chemical or substance containing a hazardous chemical in the following circumstances:

6(1) When, in the opinion of the Director, the use, handling, storage, sale, manufacture, disposal or display, or the method of application or of transportation of a hazardous chemical or of a substance of thing containing a hazardous chemical

(a) causes or is likely to cause impairment of the quality of the environment for any use that is being or is likely to be made of it,

(b) causes or is likely to cause injury or damage to property or to plant or animal life,

(c) adversely affects or is likely to adversely affect the health or safety of any person,

(d) impairs or is likely to impair the safety of any person, or

(e) renders or is likely to render, directly, or indirectly, any property or plant or animal life unfit for use by man,

The Director could, whether or not the chemical, substance, or thing was named in the schedule, make an order called a "chemical control order" directed to the person responsible for the hazardous chemical, or substance or thing containing the hazardous chemical, and was required to cause a copy of the order to be served on the person to whom the order was directed.

Section 7.1 specifically required such persons to undertake clean-up of hazardous chemical spills, and authorized Alberta Environment to undertake such clean-up where the person responsible failed to do so. The costs were then payable by the person responsible for the chemical.

Not all hazardous chemicals fell within the scope of the $H C A$. Several hazardous chemicals were exempt from the $H C A$, most notably, the majority of oil industry waste. Section 2 of the Hazardous Chemicals Regulation ${ }^{15}$, stated:

2. The following hazardous chemicals are exempt from the Act and this regulation if they are disposed of as waste:

(f) drilling fluids, produced waters, oily waste, fracture fluids, reformates, completion fluids, process and run-off waters, spent iron sponge or similar sweeteners and waste treater hay resulting from the exploration, development or production of crude oil or natural gas approved pursuant to the Oil and Gas Conservation Act and the regulations under that Act or the Pipeline Act and regulations under that Act;

The hazardous waste exemption is narrowed slightly under the $A E P E A$, and the regulations made pursuant thereto. However, the exemption of oilfield waste has been left largely intact, with responsibility for administration and enforcement of waste management 
practices for the upstream oil and gas industry assigned primarily to the Energy Resources Conservation Board ("ERCB").

\section{Safety Codes Act}

The $S C A$, which is currently being proclaimed in stages, repeals the Fire Prevention $A c t^{16}$ and the Alberta Fire Code ${ }^{17}$, and promises to increase the stringent requirements imposed under the former legislation with respect to the regulation of underground storage tanks. This Act, along with the M.U.S.T. (Management of Underground Storage Tanks) program created by Alberta Environment and Alberta Labour, will be the primary sources of law and policy in respect of underground tank decommissioning.

\section{Extension of Liability Under Prior Environmental Statutes to Past Owners}

Under the prior statutory regime, the regulatory and statutory requirements to clean up on-site contamination were reasonably straightforward. In respect of ongoing operations, the more difficult problem related to the scope of statutory liability in those cases where the owner/operator of the facility was insolvent or untraceable, or where the owner of a site which had no ongoing industrial activity, discovered contamination resulting from operations undertaken by prior occupants of the site.

In such cases, Alberta's environmental legislation appeared to have significant gaps. Neither the $C W A$, the $C A A$ nor the $H C A$ required prior approval of abandonment or decommissioning activities. Moreover, pollution control orders under the $C A A$ and $C W A$ respectively, applied only to the owner or operator of the plant, structure or thing which was the source of the pollutant. Stop orders under the $C W A$ and $C A A$ appeared to apply to a somewhat broader group of persons (i.e. anyone who had contravened the Acts, regulations or a license), but were restricted in their scope to requiring those persons to cease the impugned activity, rather than carrying out remedial work. Chemical control orders had a wider impact, in that they could be directed at the owner of a hazardous substance and as well, at the person having charge, management or control of it, or of its handling, storage, use or transportation.

In cases involving the $C W A$ and $C A A$, it was not possible, however, for a past owner of a contaminated site to be ordered to undertake a clean-up of that site, nor to be induced to pay for the cost of the clean-up undertaken by the current owner or by Alberta Environment. Such a party was not an owner or operator of a "plant, structure or thing" as defined in either the $C A A$ or the $C W A$. While a past owner may have been a person who "has contravened the $C W A$," as that term was used in the stop order provisions of that statute and the $C A A$, such stop orders were prospective in nature and appeared to have no application to past owners. 


\section{APPLICATION OF THE ALBERTA ENVIRONMENTAL PROTECTION AND ENHANCEMENT ACT TO A PROGRAM OF INDUSTRIAL SITE DECOMMISSIONING}

The AEPEA came into force on September 1, 1993. It contains much more stringent provisions concerning facility abandonment than prior Alberta environmental laws. It also prescribes significantly increased penalties for non-compliance, wider enforcement powers for Alberta Environment and more public consultation in the approval process.

In addition, the provisions of the $A E P E A$ capture a broader class of persons responsible for pollution-causing activities and specifically create and impose personal liability upon directors and officers of corporations that have committed an offence under the Act. ${ }^{18}$

With respect to site decommissioning, liability is directly imposed on "operators" of a facility by virtue of the approval process and reclamation obligations prescribed by the Act. In addition, liability may also be indirectly imposed upon other persons connected with the site as a result of pollution-causing events occurring during the decommissioning process or past contamination discovered as a result of the decommissioning.

\section{A. REGULATION OF PLANTS UNDER THE AEPEA - APPROVALS FOR DECOMMISSIONING AND THE RECLAMATION PROCESS}

\section{Approvals for Decommissioning}

Almost all industrial plants in Alberta will require approval under AEPEA. The general requirement in the Act is that no person shall commence or continue an "activity" unless they apply for and obtain the requisite approval. ${ }^{19}$ Depending on the type of plant, existing facilities will operate under one of five different classes of approvals (Classes A to E). Most industrial plants (other than waste management facilities and sweet gas processing plants) will fall under the Class " $B$ " approval category.

A list of "activities" for which an approval is required is provided in Schedule 1 to the Act and includes "the construction, operation or reclamation" of various types of plants. While it appears that the intention of the AEPEA is to provide for one single approval for the construction, operation and reclamation of a plant, the wording in Schedule 1 and the regulations does not render this certain. It is important to note that the definition of "activity" includes each of the construction, operation or reclamation of a plant. Accordingly, based on the wording of the above provision, it is arguable that separate approvals may be required under the $A E P E A$ for the reclamation of industrial sites, at least in those cases where reclamation and abandonment procedures have not been addressed in the original approvals issued for the facility. This has important consequences with respect to the decommissioning of plants as it potentially subjects any proposed reclamation of an industrial plant to the environmental impact assessment and Division 
2 approval processes in the Act. This is a marked departure from the prior legislation which did not require independent approvals with respect to the decommissioning process other than the occasional requirement to secure a reclamation certificate. Further, it is not entirely clear how the $A E P E A$ will handle prior approvals such as those under the $C A A$ and $C W A$ which may have vague or unduly onerous provisions concerning reclamation or pollution.

\section{Environmental Impact Assessment Process}

The inclusion of the reclamation of a plant as an activity requiring a separate approval may trigger the Environmental Impact Assessment ("EIA") provisions of the Act. Sections 39 and 41 of AEPEA provide that where, upon an initial review by a Director, the Director is of the opinion a "proposed activity" warrants further consideration under the EIA process, the proponent may be required to prepare and submit an EIA report. Where the activity is a "mandatory activity" as listed in the regulations, and the Director is of the opinion that the proposed activity warrants further consideration, the requirement to prepare an EIA is mandatory. Where the proposed activity is not a mandatory activity, the Act prescribes various procedures and notice requirements whereby the Director is to consider whether an EIA should be ordered. Further, notwithstanding any decision of a Director, the Minister of the Environment may order an EIA with respect to any proposed activity.

The list of mandatory activities prescribed by the regulations includes most types of large industrial plants (though the regulations do exempt certain types of plants from the EIA provisions of the Act). Generally, those mandatory activities relating to energy resource development are subject to the ERCB hearing process, while non-energy related mandatory activities may be subject to a hearing by the Natural Resources Conservation Board ("NRCB") if they relate to a "reviewable project" under the Natural Resources Conservation Board Act. $^{20}$

The $A E P E A$ and the corresponding regulations generally require the proponent to prepare a detailed report concerning, among other things, the need for the activity, the potential negative social, economic and environmental impacts of the activity and alternative plans and options available to the proponent. The Act mandates public notification and consultation throughout the entire process.

As a matter of practice, it is unlikely that Alberta Environment would require an EIA to be prepared in respect of a plant decommissioning, as EIA's are, by their nature, prospective. The inclusion of "reclamation" in the definition of activities for which an EIA may be required does appear, however, to raise the possibility. 


\section{Division 2 Approval Process}

Irrespective of whether an EIA is ordered, a "Division 2" approval may nevertheless be required for future facility abandonments. Although not as expensive and timeconsuming as a full environmental impact assessment, the Division 2 approval process may have as many as thirteen different steps involving the Director, the Minister of Environment and, potentially, the new Environmental Appeal Board ("EAB") created under the Act.

As provided for in the transitional provisions of the Act, all current approvals issued under, among other things, the $C A A$ and $C W A$ will be deemed to be approvals under the $A E P E A$. However, as discussed above, since the $A E P E A$ appears to contemplate a separate approval with respect to the reclamation of a plant, it would appear that a separate approval issued in accordance with the Division 2 approval process may be necessary for any proposed reclamation after the $A E P E A$ came into effect, particularly if the issue of reclamation is not addressed in the CWA or CAA License to Operate or subsequent renewals.

Under the $A E P E A$, the applicant is required to submit a detailed application form to the Director. The information required in order for the application to be complete varies with respect to each class of activity to which the approval relates. However, a common element of each application is the requirement that the applicant provide detailed information concerning closure and reclamation plans with respect to any facilities or lands affected by the approval.

The Act also provides that notice of any application is to be given to any persons directly affected by the application. ${ }^{21}$ These persons may file a Statement of Concern setting out their concerns in relation to the proposed approval of the activity. ${ }^{22}$ Further, upon being given notice of a decision either granting or refusing the approval, either the applicant or a person affected by the approval may file a Notice of Objection with the $\mathrm{EAB}^{23}$ which is then generally required to hold a hearing under the Act. ${ }^{24}$ In conducting such hearings, the EAB will be bound by the rules of natural justice, and may order the applicant to pay for the legal and expert consultants costs incurred by its opponent. ${ }^{25}$

\section{Reclamation Provisions}

(a) Licensing

Unlike prior legislation, the $A E P E A$ imposes a discrete duty to conserve and reclaim land used for industrial operations. Subsection 122(1) states:

$\begin{array}{ll}21 & \text { Supra note } 1, \text { s. } 69 . \\ 22 & \text { Ibid. s. } 70 . \\ 23 & \text { Ibid. s. } 84 . \\ 24 & \text { Ibid. s. } 86 . \\ 25 & \text { Ibid. s. } 88 .\end{array}$


122(1) An operator must conserve and reclaim specified land and secure a reclamation certificate in respect of the conservation and reclamation.

Subsection 119(f) defines "specified land" by reference to the regulations. The Conservation and Reclamation Regulation ${ }^{26}$ defines "specified land" as land that is being or has been used or held for or in connection with:

(i) land used solely for the purposes of an agricultural operation,

(ii) subdivided land that is used or intended to be used solely for residential purposes, or

(iii) any part of any unsubdivided land that is the site of a residence and the land used in connection with that residence solely for residential purposes;

Neither the Act nor the Conservation and Reclamation Regulation establishes a time frame within which reclamation must be undertaken. This leaves open the possibility that operators can undertake a selective program for sites that have not been fully reclaimed as of the date of proclamation of the AEPEA, provided that they are prepared to continue to pay surface rights compensation where applicable.

Subsection 122(2) of the Act does, however, enable Alberta Environment to trigger the reclamation duty, and in doing so, impose a time frame:

122(2) Where this Act requires that specified land must be conserved and reclaimed, the conservation and reclamation must be carried out in accordance with

(a) the terms and conditions in any applicable approval,

(b) the terms and conditions of any environmental protection order regarding conservation and reclamation that is issued under this Part,

(c) the directions of an inspector or the Director, and

(d) this Act.

Thus, where Alberta Environment determines that reclamation should proceed immediately, it may issue either an environmental protection order or a "direction" requiring an "operator" to do so. It should be noted that subsection 119(b) defines "operator" broadly so as to include both current and past operators.

For facilities licensed under the $A E P E A$, such as gas plants or oil sands recovery operations, an obligation to reclaim may also arise under the terms and conditions of approvals issued pursuant to the Act. Two types of approvals are of concern. 
The first pertains to specific approval of reclamation activities associated with operations involving large scale surface disturbance historically governed by the Development and Reclamation Plan approval processes established under the previous Land Surface Conservation and Reclamation $\mathrm{Act}^{27}$ and regulations. These are set out in Division 3 of the Activities Designation Regulation ${ }^{28}$ and include:

(a) the opening up, operation or reclamation of a mine, oil sands site or heavy oil site;

(b) exploration operations;

(c) the construction, operation or reclamation of a pipeline or transmission line;

(d) the opening up, operation or reclamation of a pit or quarry;

(e) the opening up, operation or reclamation of a peat operation;

(f) the construction, operation or reclamation of a coal processing plant.

The application requirements for such activities are set out generally in the Approvals Procedure Regulation. ${ }^{29}$ For reclamation certificates in particular, reference should also be made to Division 1 of the Conservation and Reclamation Regulation. Division 2 of that regulation also specifies the considerations to be taken into account by Alberta Environment in determining the amount and form of financial security to be provided to ensure completion of conservation and reclamation of specified land in accordance with s. 120 of the Act.

For activities not requiring specific approval of reclamation (i.e., those not listed in Division 3 of the Activities Designation Regulation), a duty to reclaim affected lands may also arise as a condition of the generic approval issued in respect to the facility itself. For example, Division 2 of the Activities Designation Regulation, in conjunction with ss. 58 and 59 of the Act, prohibits the commencement or continuation of the construction, operation or reclamation of virtually any industrial facility without an approval from Alberta Environment. Section 3(1) of the Approvals Procedure Regulation describes the information required to be provided in support of the approval application, unless otherwise directed by Alberta Environment. This includes, inter alia, a waste management plan, a description of surface disturbance impacts, and "the conservation and reclamation plan for the activity. ${ }^{130}$

As a result, to the extent that post-closure plans have been addressed in an application for a facility approval under the $A E P E A$, an obligation to reclaim the site in question within a particular time period following cessation of production may arise. Moreover, where post-closure operations have not specifically been addressed in a prior application 
or approval, the definition of "reclamation" set out in ss. 1(ccc) of the Act is so broad that virtually any activity carried out on a plant site after production has ceased might require approval under the Act. Subsection (1)(ccc) states:

"reclamation" means any or all of the following:

(i) the removal of equipment or buildings or other structures or appurtenances;

(ii) the conducting of investigations to determine the presence of substances;

(iii) the decontamination of buildings or other structures or other appurtenances, or land or water;

(iv) the stabilization, contouring, maintenance, conditioning or reconstruction of the surface of land;

(v) any other procedure, operation or requirement specified in the regulations;

It would appear, therefore, that even investigatory steps taken in anticipation of decommissioning or abandonment of an industrial plant may require approval from Alberta Environment. That in turn may set into motion a sequence of required decommissioning and abandonment activities, depending on the results of the preliminary investigation.

\section{(b) Enforcement}

In addition to new licensing requirements, the AEPEA also differs from the LSCRA in terms of the extent and nature of liability imposed upon those operators who fail to reclaim land in accordance with the Act. First, the $A E P E A$ imposes penalties of up to $\$ 50,000$ in the case of an individual, and up to $\$ 500,000$ in the case of a corporation for failure to properly reclaim land. ${ }^{31}$ Where a person knowingly fails to comply with a term or condition of an approval relating to the reclamation of a plant, the fine may be up to $\$ 1$ million in the case of a corporation, and $\$ 100,000$ in the case of an individual. ${ }^{32}$ the $A E P E A$ also empowers a court with a host of additional creative sentencing options including, among other things, ordering that the offender publish the facts relating to the conviction, directing that the offender notify any person affected by the offender's conduct of the facts relating to the conviction, directing the offender to perform community service work, and directing the offender to compensate the Minister for the cost of any remedial or preventative action that was made necessary by the act or omission that constituted the offence. ${ }^{33}$ Section 207 of the Act also provides for a civil cause of action against the offender in favour of any person who has suffered loss or damage as a result of the conduct that constituted the offence.

The Act also allows for the issuance of environmental protection orders ("EPO") either before or after a reclamation inquiry. Generally speaking, an EPO directs the recipient, 
at its own cost, to undertake remedial measures necessary to restore the environment and to perform other administrative matters relating to the restoration. This order may also relate to other locations where an inspector is satisfied that off-site damage has occurred as a result of the operator's activities. In addition to the specific requirements of an EPO under the reclamation provisions of the Act, s. 227 prescribes further general requirements that may be included in an EPO. This section is useful in providing a general overview of the content of an EPO:

227(1) In addition to any other requirements that may be included in an environmental protection order, such an order may contain provisions

(a) requiring the person to whom it is directed

(i) to maintain records on any relevant matter,

(ii) to report periodically to the Director,

(iii) to prepare environmental audits for submission to the Director,

(iv) to submit to the Director any information, proposal or plan specified by the Director setting out any action to be taken by the person with respect to the subject-matter of the order, and

(v) to take any other measure that the person issuing the order considers necessary to

(A) facilitate compliance with the order, or

(B) protect or restore the environment,

(b) fixing the manner or method of, or the procedures to be used in, carrying out the measures required by the order, and

(c) fixing the time within which any measure required by the order is to be commenced and the time within which the order or any portion of the order is to be complied with.

If an EPO was issued to more than one person, all persons are jointly responsible for carrying out the terms of the order and are jointly and severally liable for the payment of the costs of doing so. ${ }^{34}$

The Act also prescribes harsh penalties for those who fail to comply with an EPO. First, a fine of up to $\$ 100,000$ in the case of an individual, or $\$ 1$ million in the case of a corporation, may be imposed on any person who knowingly contravenes an EPO. ${ }^{35}$ Where a person or corporation unknowingly contravenes an EPO, the fine is $\$ 50,000$ and $\$ 500,000$ respectively ${ }^{36}$ With respect to the latter offence, a defence of due diligence is available where the accused established that he or she took all reasonable steps to prevent the commission of the offence. ${ }^{37}$ Second, the Court of Queen's Bench of Alberta may, 
on application by the Minister, issue a compliance order to any person directing that person to comply with the EPO. ${ }^{38}$ Failure to comply with a compliance order may be the subject of contempt proceedings. Finally, the Director may take whatever actions are necessary to carry out the terms of the order and recover the costs in an action in debt against the recipient. ${ }^{39}$

Liability in respect of plant reclamation does not cease upon the issuance of a reclamation certificate. One of the more contentious provisions found in the AEPEA is the ability of the Director to issue an EPO after the issuance of a reclamation certificate in certain circumstances where further work is warranted that was not apparent to the inspector at the time that the reclamation certificate was issued..$^{40}$ In this regard, the operator of any plant requiring an approval is responsible for 25 years from the date of the issuance of the reclamation certificate. ${ }^{41}$ This provision applies only where the reclamation certificate is issued under the AEPEA and not under the LSCRA.

Finally, as mentioned earlier, the Act and regulations provide that any operator who is engaged in an activity that requires approval or that is designated as subject to the security provisions of the regulations, may be required to provide security with respect to the obligation to conserve and reclaim the land. ${ }^{42}$ The amount of security is to be sufficient to ensure the completion of the reclamation and is to be determined by the nature, complexity and extent of the activity, the estimated costs of reclamation and the probable difficulty of the reclamation. This security may be forfeited where the operator has not complied with an EPO issued under the conservation and reclamation provisions of the Act.

Determination of the type and amount of financial security is governed by Division 2 of the Conservation and Reclamation Regulation. These provisions replace predecessor procedures set out in Part 7 of the Land Conservation Regulations ${ }^{43}$ promulgated pursuant to the LSCRA. For industry, the new security provisions are a mixed bag. While Alberta Environment has wider latitude in determining the amount and form of security required, the requirement for security to be posted at all is no longer a matter of discretion, at least in respect of the "Division 3" activities described earlier. Moreover, subsection 17(2) of the Conservation and Reclamation Regulations empowers the Minister to designate other activities as ones for which financial security is to be provided. Whether that power will be used in the future remains to be seen, and will likely depend on the performance of industry, both generally and by sector, in voluntarily undertaking appropriate decommissioning and reclamation programs.

Ibid. s. 230.

Ibid. s. 231.

Ibid. s. 127(2).

But note that there is no time limitation with respect to the issuance of an EPO under the contaminated site provisions of the AEPEA, see discussion of contaminated sites provisions, infra at 275.

Ibid. s. 120.

Alta. Reg. $125 / 74$. 


\section{B. INDIRECT LIABILITY AS A RESULT OF POLLUTION CAUSING EVENTS}

\section{Contaminated Sites Provisions}

While Alberta's prior environmental regime, for the most part, applied only to current operators of plants, the provisions of the $A E P E A$ in general, and those relating to contaminated sites, in particular, extend much further to effectively capture all persons who have handled the offending substance, all owners and previous owners of the contaminated site and any other person who the Director considers responsible for the contamination.

Liability under the contaminated sites provisions is initiated by the Director designating a site as contaminated. This designation may be made notwithstanding that a reclamation certificate was issued in respect of the site, that the release of the offending substance was in accordance with the Act or an approval, or that the offending substance originated from a source other than the contaminated site. ${ }^{44}$ However, it should be noted that a designation by the Director of a site as contaminated does not specifically result in any statutory liability against any person. Rather, the actual imposition of liability is effected by the Director issuing an EPO to a "person responsible for a contaminated site. ${ }^{115}$ In this regard, the Director has the discretion as to whether to issue an EPO and to whom such an order is to be issued.

Once a site has been designated as a contaminated site, a determination must be made as to the "persons responsible for the contaminated site" as defined in the Act. For the purposes of this discussion, "persons responsible for the contaminated site" may be grouped into three general categories: (a) persons responsible for the substance; (b) owners of the contaminated site; and (c) miscellaneous persons responsible.

\section{(a) Persons Responsible for the Substance}

Any person who owns, owned or has charge, management or control of the substance is considered a person responsible for the contaminated site. The Act specifically includes, under the "handlers" category, all those who manufacture, treat, sell, handle, use, store, dispose, transport, display or apply the offending substance. In addition, any other person who the Director considers to have been responsible for causing or contributing to the release of the substance into the environment is also a person responsible for the contaminated site. Accordingly, under this category, the Act includes virtually anyone who is or has been connected with the handling of the offending substance.

Imposition of liability on all current and past owners of the contaminants on site also has the potential to create numerous and complex disputes as to the proper apportionment of liability. For example, abandoned industrial landfills may contain wastes received from hundreds of sources. Gas processing facilities, the production through which is usually 
owned in kind by working interest owners in the plant, may have landfills on site or sludges in waste ponds containing by-products which may, at law, also be owned by that same group of working interest owners.

\section{(b) Owners of the Contaminated Site}

This category captures (i) the owner of the contaminated site and (ii) any previous owner of the contaminated site who was the owner at any time when the substance was in, on or under the contaminated site. Thus, this category captures owners of the sites solely by virtue of their being owners, and regardless of whether they are aware of the substance or are in possession of the site.

\section{(c) Miscellaneous Persons Responsible}

Finally, the last category of "persons responsible" includes all successors, assignees, executors, administrators, receivers, receiver-managers or trustees of a person referred to in the above two categories. In addition, a person who acts as the principal or agent of any of the persons mentioned above is also a "person responsible." Of particular importance to those people who are acting in the capacity of executor, administrator, receiver, receiver-manager or trustee in respect of a person responsible for a contaminated site is subsection 224(3) of the Act which limits that person's liability to the value of the assets that the person is administering in respect of the contaminated site.

\section{Factors to be Considered}

While the concept of a person responsible for a contaminated site may appear at times to be overly broad, the Act does give the Director the discretion to first determine whether to issue an EPO, and second, to whom such an order is to be issued. Factors that the Director is to consider are listed in subsection 114(2) of the Act and it would appear that the Director is to attempt to attribute the degree of responsibility for the contaminated site based on a combination of such factors as ownership of the site, cause of the contamination, knowledge of the contamination, due diligence and disclosure.

\section{(a) Ownership of the Site}

Ownership appears to be a very important criteria in assessing responsibility for a contaminated site. Generally, the AEPEA focuses on the acquisition of the site as a reference point for determining liability. As a general principle, it would appear that a person acquiring a contaminated site is, on the face of it, responsible for the contamination unless he or she did not know, could not have known and took all reasonable steps in ascertaining whether the site was contaminated before becoming an owner. This is not restricted to current owners but to all previous owners who acquired a previously contaminated site. As an additional factor, the Director is to consider the price the owner paid for the site and the relationship between that price and the fair market value of the site had the substance not been present in, on or under it. Presumably, this section is intended to capture those persons acquiring the site and who pay a lesser 
amount due to possible contamination or lack of due diligence concerning the discovery of the contamination.

\section{(b) Cause}

The Director is to consider when the substance became present in, on or under the site, whether the presence was caused solely by the act or omission of an independent third party, whether the person contributed to further accumulation or the continued release of the substance on becoming aware of same, whether a person dealing with the substance followed applicable enactments and accepted industry standards of practice in effect at the time and whether the person took all reasonable care to prevent the presence of the substance on the site.

\section{(c) Disclosure}

Finally, the Director is to consider disclosure of contamination by a previous owner upon disposing of the site.

Presumably after taking into account all of the factors listed in subsection 114(2), the Director will then decide to whom an EPO is to be issued. If more than one person responsible is to be issued an EPO, the Director is also empowered to apportion the cost of the clean-up. ${ }^{46}$ While the factors listed in subsection $114(2)$ do not specifically apply to the apportionment of costs, it would be fair to assume that such factors would have some bearing. Where the Director issues an EPO to more than one person and does not apportion the cost, those persons are jointly responsible for carrying out the terms of the order and are jointly and severally liable for payment of the costs of doing so. ${ }^{47}$ Where the Director does apportion the cost, the parties are only liable as to the share of the costs apportioned to them.

The content of an EPO issued to a person considered responsible by the Director is virtually unrestricted. Under subsection 114(4) an EPO may require the recipient to "take any measures the director considers are necessary to restore or secure the contaminated site and the environment affected by the contaminated site." In addition to the above, the content of the EPO under s. 114 may include, but is not limited to, any or all the measures specified in respect of environmental protection orders issued under s. 102 of the Act concerning the release of substances. Finally, pursuant to s. 116 the Minister may pay compensation to any person who suffers loss or damage as a direct result of the application of the contaminated sites provision. Under s. 210, the government may recover in an action in debt against any person who is convicted of an offence under the Act, the costs incurred by the government in compensating a person in accordance with s. 116 where the compensation is payable as a result of the offence. 
The Act does provide for a person responsible to become involved after a contaminated site designation but before the issuance of an EPO. After the Director has given notice of the contaminated site to all persons responsible, any person who is affected by the designation may submit a Statement of Concern within thirty days setting out his or her views on remedial measures. ${ }^{48}$ Presumably, in conjunction with the Statement of Concern, the person responsible may prepare for the approval of the Director, a remedial action plan in respect of the contaminated site and enter into an agreement with either or both the Director and the other persons responsible to provide for remediation and apportionment of the costs. In order for the agreement to be valid, it must be approved by the Director. The effect of entering into an agreement (provided that it is carried out in accordance with its terms) is that the Director may not issue an EPO under s. $114 .^{49}$

EPO s, including those in respect of contaminated site designation and apportionment orders, are subject to appeal to the Environmental Appeal Board ${ }^{50}$ and subsequent variation by the Minister of the Environment.

For oil and gas facility working interest owners, the importance of the contaminated sites provisions of the Act in the context of plant decommissioning and abandonment is twofold.

First, where a production facility has not been properly reclaimed post-closure, and as a result may cause significant adverse effects to the environment, both current and past working interest owners may become subject to an EPO requiring cleanup of the site. Therefore, it is important that persons acquiring or disposing of working interests attempt to protect themselves against such future liability through appropriate representations, warranties and investigations. Second, because a contaminated site designation and ensuing EPO can be issued irrespective of whether a reclamation certificate was granted for the operation in question, the much publicized "limitation period" for issuance of conservation and reclamation related environmental protection orders of five years (for well sites) and 25 years (for plants) ${ }^{51}$ may be a somewhat hollow assurance. The fact that a reclamation certificate may have been granted for a facility such as a well site may not necessarily protect its past working interest owners from future cleanup liability.

\section{Release Provisions}

Decommissioning activities themselves may give rise to liability under the $A E P E A$, either in respect of unauthorized releases during the decommissioning process itself or as a result of discovering that an unauthorized release has recently occurred. 


\section{(a) Releases During Decommissioning Process}

Generally, the release provisions are concerned with two types of releases. First, releases contrary to an approval ${ }^{52}$ may result in a fine, an enforcement order or the issuance of an EPO. Second, the Act also contains more general provisions relating to releases not governed by the Act, the regulations or an approval, which cause or may cause an "adverse affect." 53 "Adverse affect" is defined in $\mathbf{s .} 1$ of the Act as meaning "impairment of or damage to the environment, human health or safety or property." Contravention of this provision may also result in a fine, enforcement order or an EPO to a person responsible for the substance. "Person responsible" with respect to a substance is defined in $\mathbf{s .} 1$ of the Act to includes (i) the owner or previous owner of the substance or thing; and (ii) every person who has or has had charge, management or control over the substance. Thus, an EPO can be issued not only to an approval holder but to other persons who may be an owner or previous owner of the substance, all current and past "handlers" of the substance and their successors, receivers, agents, etc. ${ }^{54}$

The content of the EPO generally requires the person responsible to take any measures that the Director considers necessary to restore the environment. ${ }^{55}$

\section{(b) Duty to Report Unauthorized Releases}

During the reclamation process, it is quite possible that the persons undertaking the reclamation will discover that an unauthorized release is occurring or has recently occurred. The AEPEA requires any person who releases or causes or permits the release of a substance that has caused an "adverse effect" to report the release to specified parties including, the Director of the Environment, the owner of the substance, the person having control of the substance and any other person that may be directly affected by the release. ${ }^{56}$ In addition, the person responsible for the substance is required to immediately take all reasonable measures to remedy the effects of the release. ${ }^{57}$ Failure to report a release is an offence under the Act and the offender is liable to a penalty of $\$ 50,000$ in the case of individual and $\$ 500,000$ in the case of a corporation.

The scope of the release reporting provisions poses a dilemma for energy companies which have a large number of abandoned, but not fully reclaimed facilities in their asset portfolio. At issue is whether the discovery of sub-surface contamination on locations previously operated by the company or a corporate predecessor automatically triggers an obligation to report the "release" under current legislation and, consequently, an immediate cleanup obligation. If so, companies may be reluctant to conduct comprehensive site investigation programs for fear that immediate large scale and unbudgeted reclamation expenditures would be required simply as a result of having undertaken a preliminary

Supra note 1, s. 97.

Ibid. s. 98.

Ibid. s. 102.

See for example ibid. s. 227.

Ibid. s. 99.

Ibid. s. 101. 
investigation of the scope of potential work to be done over a period of time. This concern must be balanced against the benefits (and for planning purposes, the necessity) of obtaining an informed assessment of the magnitude of potential environmental liabilities and the projects required to minimize that liability as a starting point for long term risk management planning and budgeting.

\section{REGULATORY ASPECTS OF OIL \& GAS FACILITY RATIONALIZATION AND DECOMMISSIONING}

Decommissioning of industrial facilities can take place for a number of reasons, including economic downturns, plant obsolescence, or inability to meet increasingly stringent environmental standards. In the natural gas industry, decommissioning may also be precipitated by declining deliverability of natural gas produced in the area serviced by the production facilities in question. Simple economics dictate that if all of the gas production in an area can be processed at one plant (preferably the one which has the highest efficiency and environmental performance) rather than two or three plants, rationalization of processing capacity should and will occur.

For decades, the energy industry in Alberta has been highly regulated. Virtually every activity undertaken in oil and gas exploration, production, processing and transportation requires ERCB approval..$^{58}$ Included in these approvals are pipelines (licensed under the Pipeline $A c t^{59}$ ), and gas processing plants (authorization for which must be obtained pursuant to s. 26 of the Oil and Gas Conservation Act $^{60}$ ).

In considering applications for gas plants (or "schemes of processing", to use the words employed in the Oil and Gas Conservation Act), the ERCB has traditionally examined a variety of issues. The overriding issue is whether the scheme of processing is in the public interest. Sub-issues to the public interest determination include:

1. Whether the processing scheme constitutes efficient, economic and orderly development of resources in the area;

2. Whether the processing scheme will create unacceptable socio-economic impacts;

3. Whether the processing scheme will create unacceptable environmental impacts;

4. Whether the gas to be processed could be more efficiently or economically processed at existing facilities;

5. Whether the raw gas processed by the plant can be safely transported; and

ss For a discussion of the manner in which the ERCB exercises jurisdiction over energy development in general, and the environmental impacts of energy development in particular, see F.M. Saville \& R.A. Neufeld, "The Energy Resources Conservation Board of Alberta and Environmental Protection" (May 1989) 2 C.J.A.L.P., 287-313. 
6. Whether there is support for the processing scheme among the general public and among gas producers with reserves in the area.

Similar considerations apply in respect to pipeline permit applications considered by the ERCB.

Where regional processing capacity rationalizations take place, the antecedent ERCB approval processes must, to some extent, be unravelled. For example, the processing scheme approval for the surviving plant will have to be amended to authorize the addition of new fields previously serviced by the plant(s) to be closed. The addition of new production may, in turn, give rise to new issues which were not addressed when the plant was originally approved, such as an extension to the projected operating life of the plant, or the application of new sulphur dioxide emission standards to the facility. Similarly, transportation of raw gas production to the "surviving" plant may involve reversal of flows in some cases, or the installation of entirely new pipeline segments in others. With different pipeline volumes and configurations, new safety issues may also arise in respect of pipeline design (i.e. location of E.S.D. valves) or emergency response planning.

For the plants to be mothballed, ERCB approval may not strictly be required. As discussed earlier, no specific approval was required for decommissioning under the $C A A$ or $C W A$, either. Under the $A E P E A$, however, reclamation approval may be required, and it is at least conceivable that the environmental impact assessment provisions of the $A E P E A$ could also be triggered.

The environmental approval process contemplated under the $A E P E A$ (particularly where a formal EIA is required) has the potential to be convoluted, expensive and time consuming. The legislation places heavy emphasis on public involvement, on both a formal and informal level. Input from the public is to be sought in respect of setting the terms of reference for EIA's, and throughout the Division 2 approval process. Moreover, a new tribunal, the EAB, is to be established to consider appeals by industry or directly affected members of the public from, among other things, decisions to approve or refuse environmental approvals.

The AEPEA's effort to provide for effective public input is laudatory. No enlightened member of industry will deny that an opportunity must be provided to the public to comment and effectively present their views on industrial developments.

Where industry has raised legitimate objections to public hearings in the past, however, is where multiple hearings are required in respect of the same project before different regulators. Under the first version of the $A E P E A$, published for discussion purposes only, multiple hearings for major energy developments would have been a distinct possibility ${ }^{61}$ The inefficiency of that approach was apparently acknowledged by the government. As finally enacted, the AEPEA provides that the EAB must dismiss a notice of objection if in the EAB's opinion:

87(5)(b)(i) the person submitting the notice of objection received notice of or participated in or had the 
opportunity to participate in one or more hearings or reviews under the Natural Resources Conservation

Board Act or any Act administered by the Energy Resources Conservation Board at which all of the matters included in the notice of objection were considered,... [Emphasis added]

For groups of companies involved in gas processing capacity rationalization, this provision provides a degree of assurance that duplicate hearings will not be required in respect of the environmental issues arising at the surviving plant. For example, if the issue of sulphur recovery standards is addressed in the application to amend that plant's processing scheme approval, it will not then be the subject of a hearing before the EAB.

What is less clear, however, is the manner in which environmental issues at the plant(s) scheduled for decommissioning will be handled. This is problematic because approval of the approach to decommissioning may be of fundamental importance to the entire rationalization scheme. The companies involved may find it unacceptable to have highly interrelated components of an integrated rationalization plan governed by different boards (the ERCB and the EAB) with different philosophies, statutory mandates and composition.

To resolve this problem, processing capacity rationalization participants should seriously consider joining together to make a single, "omnibus" application to the ERCB. The application should describe all of the activities required to implement the plan. This would include any modifications at the surviving plant(s). It would include all pipeline reversals, looping and new laterals. It would include, if critical to the overall plan, any modification to gas sales or products lines and perhaps any associated applications to deal with unresolved equity concerns as between working interest owners in the area affected. Finally, it would include a detailed description of the decommissioning and reclamation activities at the plant(s) scheduled for closure.

A comprehensive approach such as this may at first appear to be unwieldy. In the writers' opinion, however, this may be superior, from a strategic perspective, to filing piecemeal applications with the ERCB and running the risk that hearings before the new EAB (complete with funded interventions) will be required for aspects of the plan which were not addressed by the ERCB.

It is only by fully describing all environmental matters associated with an application to the ERCB that a proponent can gain protection against a duplicate hearing process under the $A E P E A$.

For a stand-alone gas plant decommissioning, different regulatory considerations arise. At present, the ERCB has chosen not to assert formal jurisdiction over gas plant closures. Instead, ERCB staff have worked together with the company and Alberta Environment to oversee decommissioning activity and associated public consultation programmes. Whether such an approach will survive the more formal approval process apparently contemplated under the AEPEA is a matter of speculation. Where there appears to be a significant possibility that parties may object to a specific decommissioning plan (via the appeal provisions of the $A E P E A$ ), the operator of a facility subject to ERCB jurisdiction may wish to take steps to bring the decommissioning programme under the Board's jurisdiction. The purpose of doing so would be to ensure that the agency which originally approved the plant continues as the lead agency in respect of its closure, and that any 
hearings with respect to the closure plan take place before the ERCB rather than the EAB - a new board with a different statutory mandate.

To seize the ERCB with jurisdiction in such a "stand-alone" case would require procedural inventiveness and ERCB cooperation. Two mechanisms could be considered. The first would be an application by the operator for approval of the decommissioning plan pursuant to s. 7 of the Oil and Gas Conservation Act ${ }^{62}$ for a generic "approval" of the decommissioning plan. The second approach would be to apply for an amendment to the scheme of processing itself in order to specifically approve cessation of processing activity.

To the writers' knowledge, neither type of application has been made in the past. There is, however, no reason to believe that such applications could not lawfully be made. Alternatively, the ERCB may be entitled to initiate the process itself by way of a Notice to the Operator stating that with approval of the Lieutenant Governor in Council, the Board intends to issue an order requiring decommissioning of the facility in question, and requiring a submission from the operator in respect to same.

\section{CONCLUSION}

From a legal perspective there are many reasons to properly decommission industrial facilities upon closure. While at common law, the risk of subsequent action by neighbouring landowners or plant site purchasers may be considered manageable and of finite duration, statutory liability for substance releases and contaminated sites remediation has eroded the protection traditionally offered by the effluxion of time, limitation of actions legislation, and carefully drafted contracts of purchase and sale.

From a regulatory perspective, initiation of a proper decommissioning plan may be statutorily required in any event, either as a discrete activity for which an approval is required under the $A E P E A$, or as an incident of conditions imposed in the context of antecedent operating approvals. For some industries, this will impose a new risk of being forced into a public review or hearing process. For industries such as the energy industry, where public hearings are already a fact of life, the risk created by the $A E P E A$ is that a duplicate set of hearings, dealing with marginally different aspects of the same project, might take place. At best, such duplication will result in a waste of time and money, in that the same result is achieved before two different tribunals. At worst, conflicting findings may be made. To manage that risk, it is suggested that energy project decommissioning proponents should assess at the outset of a project whether it is one which might properly be addressed by application to the ERCB. If so, serious consideration should be given to inclusion of the decommissioning plan in an application to the ERCB so as to avoid the prospect of duplicated public consultation and hearing processes. 